\title{
Wastes Generation and Management: The Case of Scrap Metal Collection in Buea Municipality, South West Region of Cameroon
}

\author{
Dr. Robert Njilla Mengnjo Ngalim \\ Lecturer / Consultant on Specified Assignment \\ Department of Development Studies, \\ Pan African Institute for Development Buea, Cameroon \\ njillamn@yahoo.com \\ Jaff Nancy Kila \\ Bachelor of Science (B.Sc.) Degree in Geography
}

\begin{abstract}
This study examined wastes generation and management, using the case of scrap metal collection in Buea Sub-division or Municipality in terms of the spatial distribution and collection, the socio-economic and environmental benefits and the problems involved in scrap metal collection as a strategy for sustainable natural resources management. Data for this study were collected using primary and secondary techniques. Field observation and questionnaires constituted the main primary data collection tools. Secondary data, published or unpublished from the registers of scrap metal collectors, the library of the University of Buea and the Internet were also important in this study. The study revealed that scrap metal collection in Buea is predominantly carried out by males between the ages of 21 to 40 years due to the physical strength needed to carry out the activity. Also, that the neighbourhoods of Great Soppo, Molyko, Bomaka and Bolifamba (Mile 16) have the highest population dealing with scrap metal collection. More so, the study revealed that the types of scrap metals collected in Buea sub division included motor parts, iron rods and gas plates which are generated from abandoned vehicles, uncompleted / demolished buildings and households. The study also revealed that scrap metal collection in Buea Sub-division fulfilled socio-economic and environmental benefits to the population. However, there were problems faced in the collection of scrap metals which included the filth of the places where scrap metals are dumped and the possibilities of generating diseases as a result of standing water. The study therefore recommended that the joint efforts of the government, council and individuals should be solicited in order to enhance scrap metal collection in Buea Sub-division which is in line with the Concept of $3 R$ in natural resources management - reduce, reuse and recycle.
\end{abstract}

Keywords: Wastes, generation, management, scrap metals, Reduce, Reuse, Recycle, livelihoods.

\section{INTRODUCTION}

Generally, "wastes" are substances or objects which are disposed off or are intended to be disposed off or are required to be disposed off by the provision of national law (Basel Convention, 2000). Wastes are usually useless materials which are no longer needed and are therefore thrown away. There are different types of wastes found on the environment. An example of a type of wastes is solid waste which is the main concern of this study. Solid wastes can be sub divided into one of three major categories: municipal solid waste which is also referred to as garbage, refuse or trash. It is generated mostly from households and commercial centres. Scrap metal is any form of metallic solid wastes which is derived from domestic, commercial and industrial activities arising from human uses (Keller, 1999; Cunningham et al., 2003). In the yesteryears, wastes disposal did not pose any difficulty as settlements or human habitations were sparse and land was considered plentiful. Scrap metal wastes disposal only became a problem within the town and cities where large numbers of people settled to congregate in relatively small area pursuits (Shaiful and Monsoor, 2003; Medina, 2000). While the population densities in urban areas increased and per capita wastes collection decreased proportionately, scrap metal management thus emerged as an essential specialised sector, keeping cities healthy and liveable (Kila, 2014; Asong, 2010).

The increased trend of poverty in Africa is alarming as shown by the 2008 United Nations Human Development Index (UNHDI) Report in which more than half of Sub-Saharan African countries are ranked at the bottom of the world (U.N., 2008). Large population of African countries are engaged in 


\section{Dr. Robert Njilla Mengnjo Ngalim \& Jaff Nancy Kila}

informal income generating activities. Scrap metal collection is one of such informal activities in which a large number of deprived and underprivileged people depend for their livelihoods that cause employment to some people. However, the sustainability of their livelihood from these metal collections that are expected to redeem them from poverty remains doubtful due to the uncoordinated manner in which the activity is carried out.

The improper management of scrap metal particularly household is linked to the systematic failure of policy makers and municipal authorities to identify most sustainable ways of dealing with such wastes. Adebaw (2008) studied household waste disposal in the urban areas of Nigeria. This study is in line with that of Asong (2010), in "Assessing Public Attitude and Development" who proposed a methodological approach to carry out research to identify the different trends in behaviour in the management of household wastes, scrap metals in Cameroon in general and Douala in particular. From this research it was discovered that the main type of wastes such as scrap metal generated income or employment in Cameroon. To the author, the pattern of waste disposal trend in Cameroon consists of improvement in waste management method and the adoption of more efficient ones such as landfills. Early humans did not worry much about waste management. They simply left their waste garbage where it dropped. Other efficient methods include incineration, recycling and waste prevention. How these four methods are utilised depend on the kind of wastes being managed. Municipal wastes are more different than industrial, agricultural and hazardous wastes that pose serious problems. Presently, in many parts of the country wastes are being dumped in containers along road sites and are being collected frequently by different company trucks found in the area. With this pattern of waste disposal, it will reduce environmental damages.

Generally, there are two types of scrap metals: ferrous and non-ferrous. Ferrous is the scrap iron and steel. This includes scrap from old automobiles from equipment, households and chromium. They are recovered by processes and consumed by secondary smelter refiners, ingotmaker foundries and other industries in this country. The ferrous and non-ferrous scrap metal can be categorised as either "home scrap" or "purchased scrap". Home scrap is scrap generated at the mill, refinery or foundry and generally re-melted and used again at the same plant. Home scrap never leaves the plant for reuse. Metals are a group of chemical elements that exhibit all or most of the following physical qualities: they are solid at ordinary temperatures; opaque, except in extremely thin films; good electrical and thermal conductors; lustrous when polished; and have a crystalline structure when in the solid state. Metals and non-metals are separated in the periodic table by a diagonal line of elements. Elements to the left of this diagonal are metals, and elements to the right are non-metals. Elements that make up this diagonal - boron, silicon, germanium, arsenic, antimony, tellurium, polonium, and astatine - have both metallic and non-metallic properties (Cunningham et al., 2003; Microsoft Encarta, 2009).

The common metallic elements include the following: aluminium, barium, beryllium, bismuth, cadmium, calcium, cerium, chromium, cobalt, copper, gold, iridium, iron, lead, lithium, magnesium, manganese, mercury, molybdenum, nickel, osmium, palladium, platinum, potassium, radium, rhodium, silver, sodium, tantalum, thallium, thorium, tin, titanium, tungsten, uranium, vanadium, and zinc. Metallic elements can combine with one another and with certain other elements, either as compounds, solutions, or intimate mixtures. A substance composed of two or more metals, or a substance composed of a metal and certain non-metals such as carbon are called alloys. Alloys of mercury with other metallic elements are known as amalgams. These metals are mostly found in nature and with their continuous use and exhaustion there is need for scrap metal recycling and reuse (Microsoft Encarta, 2009).

\section{The Problem And ObJectives}

The dumping of scrap metal wastes by the inhabitants of Buea and the low frequency of scrap metal collection has led to a situation where wastes (scrap) heaps have been spotted to be favourable breeding grounds for pests, mosquitoes and flies, thus causing illness like cholera, typhoid, malaria, as well as increasing pollution of the environment and soils. Despite the efforts by the individuals and government on the management of these scrap metals in Cameroon, Buea in the South West Region of Cameroon still faces scrap metal disposal problems. Scraps from domestic (household), offices (municipal) are commonly found around in the streets. Some metal recycling can be regarded as an environmentally friendly activity in terms of maximisation of resources, utilisation of resources, resource conservation, wastes reduction and pollution prevention, albeit energy utilisation and pollution from recycling process can be completely avoided (Kaseva and Gupta, 1996). But the need 
to investigate the socio-economic benefits of scrap metal collection for recycling and reuse is deemed essential for poverty reduction and sustainable human development. However, how secured and reliable are these socio-economic benefits for the livelihood of poor people? This study therefore intends to resolve and clarify if scrap metal collection in Buea can deliver secured and reliable livelihood or improved standard of living for poor people engaged in the activity. Wastes generation sites are supposed to be located at the outskirt of any urban centre. In quarters and homes where wastes generated on site are not specific, there are many ways in which wastes can be generated. There are organic materials which are generated from yards and gardens, food wastes and sewage sludge from treatment plants, worn out furniture and consumer products. They are very close to home settlements because they are obtained from homes. However, the focus of this study is on scrap metal collection by inhabitants of Buea which has led to employment of some people in that area. It is in the light of addressing the above burning issues that this study is instigated. The emerging question therefore is: "What are the socio-economic benefits and environmental implications/benefits of scrap metal collection in Buea sub division?" The main aim of this study is to investigate waste generation and management of scrap metals collection in Buea sub division. The specific objectives of this study are to: examine the spatial distribution and collection of scrap metals in Buea sub division; investigate the socio-economic and environmental benefits of scrap metals collection in Buea sub division; examine the problems involved in scrap metal collection as a strategy for sustainable natural resources management in Buea sub division. This study was therefore based on the following hypotheses; wastes scrap metal collection is a significant contributor to the socio-economic livelihood of those involved, and wastes scrap metal management is the sole responsibility of the government in Buea sub division.

\section{THE STUDY AREA}

Buea is found in Fako Division, South West Region of Cameroon. It is situated between latitudes $4^{\circ} 3^{\prime \prime}$ and $4^{\circ} 12^{\prime \prime} \mathrm{N}$ of the equator and longitudes $9^{\circ} 2^{\prime \prime}$ and $9^{\circ} 9 " \mathrm{E}$ of the Greenwich Meridian (Lambi, 1999). Buea was the capital of the former West Cameroon and is presently the regional headquarters of the South West Region (Map 1). It is situated precisely at the foot of the slope of Mount Cameroon, which is the highest peak in West and Central Africa at an altitude of about $4100 \mathrm{~m}$ above sea level. The town of Buea itself is about $915 \mathrm{~m}$ above sea level. Buea sub division is bounded in the South West by a portion of the Atlantic Ocean and Limbe, South by Douala, Muyuka in the East and the North-Eastern part by Mount Fako. There are a number of urbanising neighbourhoods in Buea sub division such as Great Soppo, Muea, Molyko, Buea Town and Bolifamba (Mile 16) amongst others. Given its mountainous location, Buea sub division enjoys a cool climate conducive for human habitation and the performance of human and economic activities such as agriculture and commerce.

\section{Population And Economic ACtivity}

Table1. Changing Trends of Population for Buea Municipality (1976 - 2012)

\begin{tabular}{|l|l|l|}
\hline Year & Population & Rate of change \\
\hline 1976 & 22,948 & - \\
\hline 1977 & 23,456 & 505 \\
\hline 1982 & 26,149 & 3,201 \\
\hline 1987 & 65,853 & 39,704 \\
\hline 1993 & 78,632 & 12,779 \\
\hline 1998 & 105,000 & 26,368 \\
\hline $2008^{*}$ & 141,111 & 19,387 \\
\hline $2012^{*}$ & 158,891 & 17,780 \\
\hline
\end{tabular}

Source: Sub Divisional Office, Buea (1999), Population Census Figures (1976, 1987, * Projections)

The 1976 population census placed Fako Division at 168,000 people with Buea having an estimated population of 22,948 people comprising of the natives and non natives. The second general population census of April 1987 recorded 65,853 inhabitants for Buea. It should be noted that Buea is found within the highly populated areas of Cameroon with population density of over 100 persons $/ \mathrm{km}^{2}$ (Table1). With a growth rate of 3\%, a population projection was made and it revealed that by 1997, the population would be 88,501 people. Another projection for the year 2008 made in 1998 revealed that with a growth rate of $3 \%$, the population was supposed to be 141,111 people. With this same 


\section{Dr. Robert Njilla Mengnjo Ngalim \& Jaff Nancy Kila}

growth rate of above replacement level in Buea there is a future anticipation of having a total of 158,891 people by the year 2012. The population of Buea Municipality has since 1964 witnessed a steady increase. The cause of this rapid increase is as a result of natural increase (NI) accelerated by improvement in sanitary and health facilities. Net migration within the years has also proven to be responsible for the unprecedented increase in the population of Buea Municipality. The table above illustrates the population trends and associated rate of change over the years.

Map1. Spatial Layout of Buea Sub-Division. Inset Location of the South West Region in Cameroon and Location of Fako Division in the South West Region of Cameroon

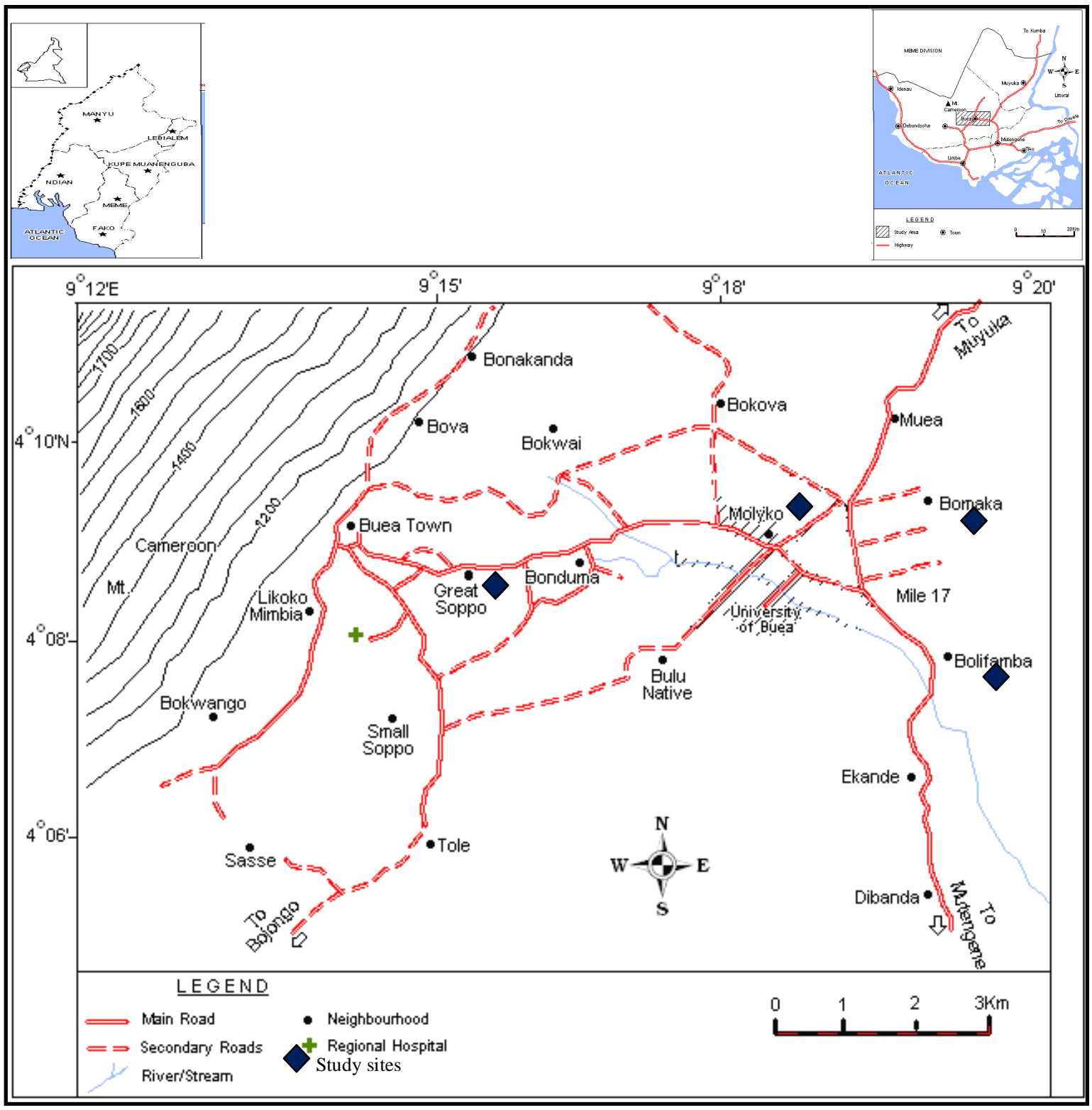

Source: Adapted from the Map of Buea, NIC Yaounde, (2005) and Ntangsi and Lum (2004)

\section{SOCIO-ECONOMIC/INFRASTRUCTURAL DEVELOPMENT}

The economy of Buea Municipality is supported primarily by an agricultural base with a number of plantations such as Cameroon Development Corporation (CDC), with an extensive banana plantation at Ekona and a Tea Estate at Tole. These plantations have employed a majority of those residing around the Buea Municipality. This has helped to reduce unemployment to an extent. Furthermore, following the recent infrastructural development, Buea has within the past 15 years witnessed a sharp increase in the number of built up areas following the creation of the University of Buea in 1993. This, settlements expanded into once forested areas. This has led to the generation of huge quantities of scrap metals. The earlier anticipations and notions that emanated about the region being unattractive are now gradually being transformed into more attractive perceptions of the region due to 
accelerated socio-economic development. However, some areas within the municipality are still remote and far from the vestiges of development and beg for a revisit in terms of infrastructural development. This is the kind of development that has led to the increase in scrap metals which is used by the population for various reasons.

\section{CONCEPTUal Framework}

\subsection{The Concept of the Three (3) Rs - Reduce, Reuse and Recycle}

This study was carried out and based on the concept of the 3Rs - Reduce, Reuse and Recycle as propounded by Chandler (2006). In the third world countries, waste collection and management in general and scrap metals in particular is a plague to the poor. This is due to the adoption of poor wastes management techniques. Figure 1 illustrates the 3 Rs initiatives or the life cycle of Reduce, Reuse and Recycle. According to this concept, individual's collective actions have a tremendous impact on scrap metal collection issues. Copious amounts of garbage resulting from consumptiondriven and densely populated societies have led wastes managers to adopt and promote an approach to reduce wastes (scrap metals) collection problems summarized by the phrase "Reduce, Reuse and Recycle". This slogan reminds consumers of the actions they can take to minimise the burdens that their wastes (scrap metals) create. Reducing wastes, reusing wastes when possible and recycling wastes into goods for tomorrow are therefore appropriate strategies which are in line with sustainable natural resources management (Cunningham et al., 2003). This is applicable to the situation of Buea where the consumption-driven nature of the increasing population produces huge amounts of wastes including scrap metals, which need to the reused or recycled for posterity.

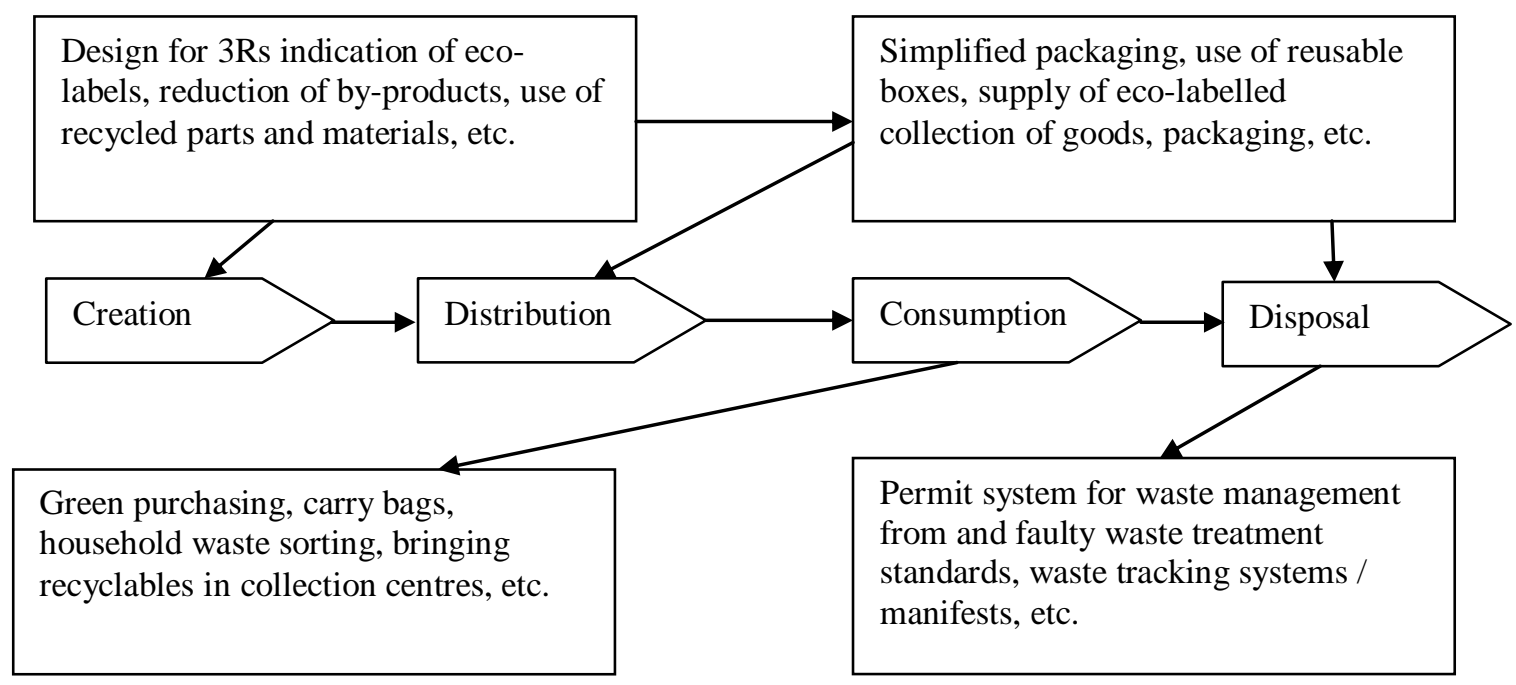

Figure1. The 3Rs Concept of Waste (Scrap Metal) Management

Source: USEPA (2006)

\subsection{Reduce}

The main idea is to minimise the quantity of waste generated. A successful waste reduction strategy would be the most effective and promising way of dealing with solid waste management as the amount of waste for disposal is minimized. But waste reduction also involves an aspect of culture on people's behaviour and attitudes (United States Environmental Protection Agency USEPA, 2006). However, the reality in Buea and Cameroon as a whole is that due to the importation of used goods from Europe, America and Asia and the increasing use of second hand dilapidated vehicles, the incidence of scrap metal disposal has been on the rise. As a result, there is need to reduce and regulate such wastes through government and customs policies that encourage the importation of quality vehicles and household appliances into the country. Waste reduction through resource use optimisation thus minimises resource wastage. Reducing the waste before it is generated is a logical way to save cost and ensure efficient natural resource utilisation. It reduces the municipal and commercial costs involved in waste collection and disposal and helps in protecting the local environment. However, a successful implementation of source reduction programme requires the cooperation of stakeholders: businessmen, industrialists, consumers, state and the local governments. 


\section{Dr. Robert Njilla Mengnjo Ngalim \& Jaff Nancy Kila}

The source reduction should be a part of community waste management plan. Source reduction activities vary widely and many factors have to be considered during their evaluation. Source reduction thus promotes product reuse, increases its lifetime and reduces the probable toxicity of the material to the environment (Asong, 2010). Generally, the methods of waste reduction include manufacturing products with less packaging, encouraging customers to bring their own reusable bags for packaging, encouraging the public to choose reusable products such as cloth, napkins and reusable plastic and glass containers, backyard composting and sharing and donating any unwanted items rather than discarding them.

\subsection{Re-Use}

Waste reuse circulates waste and avoids the use of new resources. However, reusing products delays the need for producing new products and landfilling the existing ones; and individuals buying used items get something they value for less than the cost of a new product. Metals and aluminium can be remelted and used in new products. For example, Ecuador has a refundable beverage container deposit fee that is $50 \%$ of the cost of the drink. In Finland, 95\% of the soft drink, beer, wine, and spirits containers are refillable, and in Germany, $73 \%$ are refillable (Hanan, et al., 2002). The materials are sold to commercial centres which also sell it to the end users. The materials therefore only enter the waste stream when they are used for domestic consumption. Reuse plays a valuable resource conserving role. Through the use of indigenous knowledge and simple technological innovations, there are clear evidences of reused materials in our local markets made out of disposed or used scrap metals.

\subsection{Recycle}

Waste recycling converts waste into useful products. It involves the process of separating, collecting, processing, marketing and ultimately using a material that would have been discarded or in other words, it is the recovering of waste from one process and reusing it in the same process or in another process in an environmentally safe manner (EPA, 1993). It also helps in source reduction. It has benefits similar to other forms of source reduction. It reduces reliance on landfills and incinerators. It protects human health and the environment by removing the harmful substances from the waste stream. It also conserves natural resources by reducing the demand for raw materials. Recycling reduces the volume of the waste that has to be finally dumped, which means a reduction in pollution at the waste sites. According to USEPA, recycling turns materials that would otherwise become waste into valuable resources and, it yields environmental, financial, and social returns in natural resource conservation, energy conservation, pollution prevention, and economic expansion and competitiveness. Materials which can be recycled include; metals, glass, plastics, batteries, tyres. For example, glass bottles can be crushed and melted to make new bottles or other glass items.

According to Tsiboe \& Marbell (2004), UK recycles only $11 \%$ of its household waste, Italy and Spain only 3\%, Netherlands 43\%, Denmark 29\%, and Austria 50\%. In Asia the recycling rates are different: Japan recycles over $70 \%$ of plastics and over $80 \%$ of aluminium cans. Domestic Waste recycling in Hong Kong was 35\% in 2009, as compared to $14 \%$ in 2004. Currently Singapore recycles $11 \%$ of household plastics and 29\% glass, Taiwan's overall recycling rate reached $45.49 \%$ in 2009 (Pariatamby \& Tanaka, 2014). Scrap metal recycling is an important strategy in ensuring resource conservation in Cameroon. Typical among these are iron rods and building materials made out of recycled scrap metals.

\subsection{The Waste (Management) Hierarchy}

The wastes hierarchy is a process used to protect the environment and conserve resources through a priority approach established in wastes (scrap metal) policy and legislation (Figure 2). This hierarchy establishes preferred programme priorities based on sustainability so as to ensure sustainable wastes (scrap metal) management which can be solved only through technical end of pipe solutions and integrated approaches (Fellman, 2005; Keller, 1999). The scrap metal management hierarchy indicates the order of preference for action to reduce and manage scrap metal collection and it is presented diagrammatically in the form of a pyramid. The hierarchy captures the progression of materials or products through successive stages of scrap metal management and represents the latter part of the life-cycle for each product. The aim of the waste hierarchy is to extract the maximum practical benefits from products and to generate the minimum amount of wastes. The proper application of the wastes hierarchy can have several benefits such as self employment through the 
collection of scrap metals. This is particularly true in the context of Buea which is the present study. The wastes hierarchy was divided into stages which range from scrap metal management options according to what is best for the environment. It gives top priority in preventing scrap metal wastes in the first place. If scrap metal waste is not produced then there will be no collection and disposal of such wastes. When scrap metal waste is collected, it gives price to prepare it for reuse, recycling then recovery and least of all disposal. The reduce of wastes (scrap metals) is the most vital point in the wastes hierarchy, for example, like the case of Buea scrap metal collection has reduced the mass accumulation of waste materials. These scrap metals also produce a significant benefit to the inhabitants of Buea because it has led to self employment of people through the collection of scrap metals and dividing them into smaller pieces for easy transportation. The Buea council has also helped in the reduction of solid wastes by the use of HYSACAM which passes at least three times a week to collect wastes from quarters for disposal. In some of these wastes are scrap metals which are later scavenged by youths for sale to the collectors.

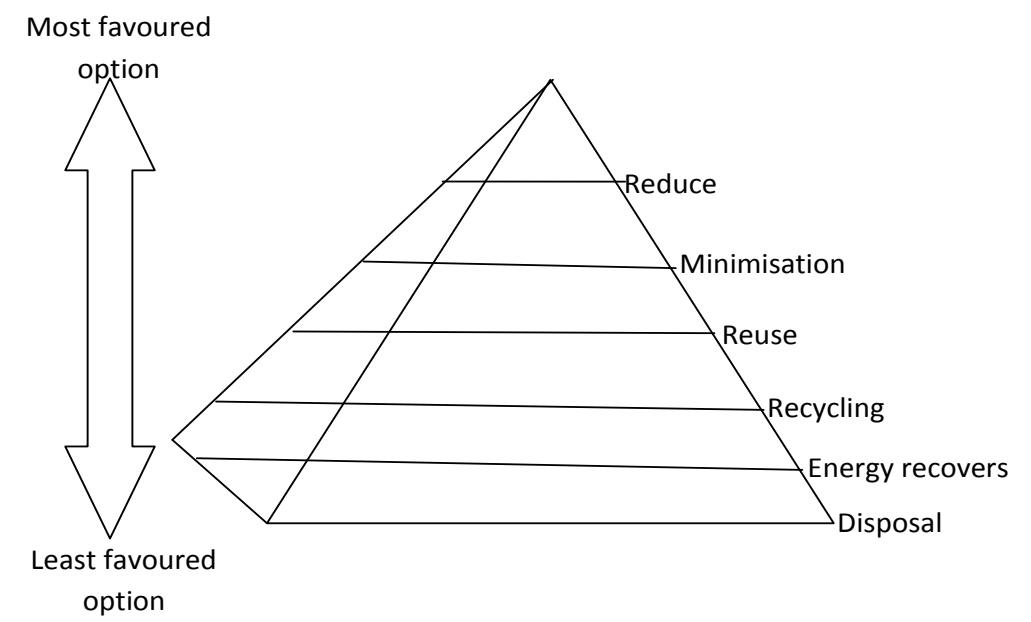

Figure2. Wastes (Management) Hierarchy

Source: UNEPA (2006)

Also, the reuse of scrap metal is the most desirable option. It is any operation where products or materials which are not wastes or which are considered wastes in one sector or use are collected and reused again for the same or different purpose for which they were intended (Cunningham, et al., 2003). This has created employment to the population thereby reducing the amount of solid wastes in our environment. Recycling of wastes (scrap metals) is the most desirable option. It is the collection of used or reused items that would be wise to be considered as wastes. This collection of scrap metals is done in Buea from households, abandoned vehicles and from uncompleted buildings. Recycling of scrap metal collection involve sorting and processing the recyclable parts or products into raw materials and then remanufacturing the recycled raw material to raw products like the case of scrap metal that are being collected from Buea and transported to Douala to recycle them into new products such as iron rods.

\section{RESEARCH MeTHODOLOGY}

The research design of this study is basically qualitative, that is, an orderly arrangement of data and intuitive or critical analysis. This orderly arrangement of data is for easy assessment. Also the analytical design is used in collecting and analysing data. Appropriate techniques such as; averages, percentages, tables and histograms were employed in this study. The target population of the study constituted the entire population of Buea sub division which stands at about 150,000 inhabitants. From this total population, a sample of 200 questionnaires were distributed to the segment of the population that deals with scrap metal collection mainly in the neighbourhoods of Molyko, Bomaka, Great Soppo and Bolifamba (Mile 16). The procedure used in the study was the stratified random sampling. Stratified because the population was broken down into those involved in the collection of scrap metals from the field and those who purchase the scrap metal for onward transportation to Douala or abroad. In each of these groups, the simple random sampling was employed in order to give each individual an equal chance of participating in the study or to avoid biasness in general. 


\section{Dr. Robert Njilla Mengnjo Ngalim \& Jaff Nancy Kila}

Primary data were collected through field observations in which information about the spatial distribution of wastes dumping sites and wastes collection sites was obtained, the types of wastes collected, the processes involved such as weighing and reduction of scrap metals into smaller pieces using axes, the population involved mostly the youths, the environment in which the scrap metals are deposited, and the loading of scrap metal for eventual transportation to Douala or abroad for recycling. This field survey enabled the work to be more practical and realistic, because the above information was obtained mainly through observations.

A semi-structured questionnaire was used to collect primary data that led to the findings of the study. The questionnaire was structured into two sections. Section contained the demographic data of the respondents in terms of sex, age, occupation, level of education, nationality, tribe and religious affiliation. The second part examined wastes generation and management of scrap metals in terms of ways of waste generation in Buea, types of scrap metals disposed off in Buea, the socio-economic and environmental benefits of scrap metal collection in Buea, the diseases associated with poorly disposed wastes in Buea, the authorities responsible for scrap metal collection and management in Buea and the possible problems faced by those dealing with scrap metal collection and management in Buea. The questionnaires also addressed opinion questions such as "in your own point of view, what can be done to manage scrap metal generation within Buea sub division?" and "in your own opinion, do you think scrap collection is the sole responsibility of the government? Data obtained using the questionnaire proved invaluable in the analyses and presentation of findings of this study. The questionnaires had both open and closed ended questions. The closed-questions were for easy analysis of responses while the opened-ended questions were for the respondents to express their views respectively.

Interviews were also conducted with managers or owners of scrap metal collection sites on the importance of the activity, those involved in the collection or scavenging process and the problems faced by the sector. Also, the scrap metal buyers were interviewed on what types of metals they buy and how much a kilogram costs.

Secondary data were collected through the reading of books and past projects. Also there was the reading of journal, books from Library which have relevant information concerning solid wastes generation and management in general and scrap metal generation, disposal and management in particular. These textbooks were relevant for literature review and conceptual framework of this study. Collected data from the field and other sources were analysed using simple statistical test, frequencies and percentages. These are simple statistical tools in which the means or average numbers of responses are obtained so that conclusions can be drawn. The analysed data were presented in tables, plates, maps, histograms and bar graphs.

\section{FINDINGS AND DISCUSSIONS}

\subsection{Demographic Characteristics}

In terms of sex distribution, the findings revealed that the males (76\%) dominated the sample population while the females constituted $24 \%$. This is because the activity of scrap metal collection requires physical strength since there is lifting of heavy objects, which most females cannot perform. Those females even employed work mostly in the receptionist of these centres and registering of weighed scrap metal.

Concerning age distribution, the findings revealed that the age group 31 to 40 years (48\%) dominated the sampled population followed by 21 to $30(44 \%)$ and under $20(8 \%)$. The age groups of more than 20 and less than 40 years are preferable due to the physical nature of the work which demands too much strength. The small percentage of under 20 are school children or dropouts who a struggling to make fast cash by indulging in scrap metal collection and marketing. There were no respondents above 41 years due to the strength requirement of the activity. Those in this age group were mostly the owners of the scrap metal centre rather than those collecting the scrap metal.

\subsection{Dumping Sites of Scrap Metal}

Table 2 shows that Molyko is the major dumping site for scrap metals as $37.5 \%$ of the sampled population shared this view. This results from the fact that apart from it being the heart of Buea, it is one of the most populated areas within Buea Sub Division, which has further encouraged the construction of houses. This has led to an increase in the generation of scrap metals such as iron rods and zinc. Bolifamba (Mile 16) with a percentage of 27.5 is a major car repairs / maintenance centre 
and also harbours the major spare part shops, thus generates high amount of scrap metals. Bomaka (17.5\%) is still an emerging area so the inhabitants do not have much of scrap metal because the population is not much, so it does not have much scrap metal collection and also it is not a business district like Molyko. However, there are a few car repair garages in Bomaka which leads to the generation of scrap metals from replaced spare parts. Also, in Soppo, only 17.5\% indicated scrap metal collection due to the presence of a few garages and human activities such as schools which have attracted the population, thereby leading to the generation of scrap metal. Scrap metals from old abandoned and/or dilapidated automobiles were mostly found in Bolifamba and Molyko where there are many car repairing workshops or garages. However, household appliances were mostly found in Great Soppo, Bomaka and Molyko due to the increasing student and working populations in these areas.

Table2. Distribution of Respondents according to Dumping Sites

\begin{tabular}{|l|l|l|}
\hline Dumping Site & Frequency & Percentage \\
\hline Molyko & 75 & 37.5 \\
\hline Bolifamba & 55 & 27.5 \\
\hline Soppo & 35 & 17.5 \\
\hline Bomaka & 35 & 17.5 \\
\hline Total & 200 & 100 \\
\hline
\end{tabular}

Source: Field work (2014)

\subsection{Knowledge of Types of Scrap Metals Generated in Buea Sub Division}

From the findings, it can be observed that $38 \%$ of the respondents concurred that the major types of scrap metals are motor (car) parts, followed by iron rods $(20 \%)$. In the same vein, $16 \%$ of the respondents said scrap metals are generated from gas plates, $12 \%$ from zinc, $10 \%$ from electronics and $4 \%$ from abandoned fridges. This is typical of rapidly urbanising neighbourhoods like Buea and its environs in Cameroon.

\subsection{Knowledge of Sources of Scrap Metal Generation in Buea Sub Division}

From Table 3, the sampled population shared the view that scrap metals are generated from abandoned vehicles especially along roadside garages and at homes. The abandoned vehicles along roadsides and homes are because of the fact that the sea port is in close proximity to Buea and this encourages the importation of cars and transporting them to Buea. Also, there is extensive hardship in the country which has caused people to be unable to maintain their cars, thus abandoning them along roadsides or garages or their homes. Also, an increase in the number of cars and garages has led to the generation of scrap metals. To add to this, the importation of old dilapidated cars into the country means that these cars are imported when their lifespan have been exhausted. The cars cannot be used for long, thus they constitute scrap metal in the short run. Secondly, the high construction of houses in Buea especially Molyko has increased scrap metal generation and collection because of the growth in population of Buea. This is due to the influence of the University of Buea as a growth pole and other educational institutions thus encouraging more building and increasing household scrap metal in Molyko.

Table3. Distribution of Respondents according to Knowledge of Sources of Scrap Metals in Buea Sub Division

\begin{tabular}{|l|l|l|}
\hline Sources of Scrap Metals & Frequency & Percentage \\
\hline Abandoned vehicles & 96 & 48 \\
\hline Household items & 72 & 36 \\
\hline Demolished / Building construction & 24 & 12 \\
\hline All the above & 8 & 4 \\
\hline Total & 200 & 100 \\
\hline
\end{tabular}

Source: Field work (2014)

The demolition of buildings has also increased scrap metal in Buea sub division. This has led to an increase in scrap metals such as iron rods and zincs (aluminium roofing sheets). Also, a building which is destroyed by fire generates scrap metal from it. Furthermore, the visit of the President to Buea led to the demolition of many houses and temporary structures along the roadsides in Buea which led to the generation of scrap metals. These metals were collected by the population to make 


\section{Dr. Robert Njilla Mengnjo Ngalim \& Jaff Nancy Kila}

fast cash. Finally, an increase in population and living standards in Buea has led to the use of many household appliances such as pressing irons, cooking appliances and fridges. When these appliances get bad the owners dispose of them in trash cans. Those involved in scrap metal collection make do with these disposed items which they collect and sell to scrap metal dealers in Buea. Also, the growth of the computer business has led to the generation of high quantities of scrap metal in Buea. In this way, youths are seen carrying heavy bags full of abandoned and/or disposed scrap metals. So of them even entice the population with small amounts so as to have their scrap metals given to them. I

This section has answered the first objective of the study which was out to examine the spatial distribution and collection of scrap metals in Buea sub division. The findings indicate that scrap metal collection in Buea sub division is mostly done in the neighbourhoods of Molyko, Bolifamba (Mile 16) Bomaka and Great Soppo. Also, the scrap metals are obtained from abandoned vehicles, demolished and uncompleted buildings and from destroyed household appliances as illustrated on the plates above. This is because of their high population concentration and space to store the scrap metals before eventual transportation to Douala or abroad for recycling. Also, these neighbourhoods have a high proportion of youthful population who are involved in the activity in order to make fast cash.

\subsection{Socio-Economic Importance of Scrap Metal Generation and Collection in Buea}

From Table 4, a majority of the sampled population said employment $(50 \%)$ is the main socioeconomic importance of those involved in scrap metal management. In the same line, $20 \%$ of the respondents indicated revenue.

Table4: Distribution of Respondents according to Knowledge of Socio-Economic Importance of Scrap Metals in Buea

\begin{tabular}{|l|l|l|}
\hline Socio-Economic Importance of Scrap Metals & Frequency & Percentage \\
\hline Employment & 100 & 50 \\
\hline $\begin{array}{l}\text { Revenue generation (both for those collecting and those } \\
\text { purchasing) }\end{array}$ & 40 & 20 \\
\hline Reduced pollution & 32 & 16 \\
\hline Enhanced sanitation & 28 & 14 \\
\hline Total & 200 & 100 \\
\hline
\end{tabular}

Source: Field work (2014)

This has resulted from the fact that many people are being employed or the council gets it revenue from scrap metal collection through the payment of taxes. Also, 16\% said that scrap metal management has reduced pollution, while $14 \%$ indicated that there has been increased sanitation in the area thanks to the collection of scrap metals which is no longer deposited haphazardly. The collected scrap metals are deposited at particular spots under the strict control of those involved in the business. In this way, the environment is constantly kept clean by the dealers in scrap metal collection and management.

From the above, it can therefore be concluded that scrap metal collection has led to socio-economic improvement in Buea Sub-division. This has led to the creation of job opportunities to many people in Buea who are employed under scrap metal collection schemes. Those employed under scrap metals include children, school dropouts and holiday makers who want to make fast cash. Children also gain from this because they pick scrap metals and sell them to those buying scrap metals. Those working in scrap metal collection are paid 35,000Frs per month. Those who work in the scrap metal collection like the school dropouts help in the breaking of scrap metals into smaller pieces which will be easily transported to the scrap metal sites and consequently in the 20 ton trucks. Also, those who pick the scrap metals in the 20 ton trucks are being paid 5,000Frs each for loading. A kilogram of scrap metal is sold for 70Frs, and it takes about two weeks to generate 20 tons truck of scrap metal. This therefore shows that scrap metal trading is a lucrative business in Buea sub division, reason why many people are involved in its operation. Scrap metal collection has led to environmental importance through the "reduce", "reuse" and "recycle" of scrap metal. This falls in line with the concept of 3Rs in resource management - Reduce, Reuse and Recycle. With increasing population and increasing demand for resources, some natural resources are not easily replenished by nature. As a result the 3Rs above are important in ensuring sustainable natural resource utilisation in Buea in particular, Cameroon in general and the world at large. Scrap metal collection has therefore led to the improvement of our environment by reducing pollution of the environment. The soils are also improved because the 
dumping of non-biodegradable scrap metals suffocates the soil leading to poor harvest. In the urban centres, scrap metals haphazardly disposed off have been known to block storm drains leading to flooding after rainstorms. Also, the recycling of scrap metals has led to the creation of employment. This is seen in people who use scrap metals to produce sawdust for cooking and other appliances used. The wheel drums of cars are used for setting fires to roast maize and plums, plantains and others.

Furthermore, the collection of scrap metals has led to reduction of scrap metals from abandoned vehicles, households / appliances, demolished buildings which are carried and sold to scrap metal collectors and later transported to Douala or aboard for recycling. This reduction of scrap metal has led to reduction of diseases such as malaria and tetanus, since some of the standing water which serves as breeding grounds for mosquitoes are eliminated. This section has presented findings on the socio-economic and environmental benefits of collection of scrap metals in Buea sub division. It shows clearly that scrap metal collection is the main source of livelihood to those involved either as collectors / scavengers of scrap metals and those who own the collection centres. In terms of the environment, pollution and unsanitary conditions are minimised as a result of scrap metal collection. This is in line with the concept of 3Rs in natural resources management - Reduce, Reuse and Recycle. From the findings, it is therefore logical to conclude that wastes (scrap metal) collection is a significant contributor to the socio-economic livelihood of those involved in Buea sub division.

In relation to the second objective which was to investigate the socio-economic and environmental benefits of scrap metals collection in Buea sub division, the findings revealed that scrap metal collection and purchase is a major source of livelihood to those involved in it. It employs the youths or people of less than 40 years who go around scavenging for scrap metals from open dump sites or those found along the roadsides. Also, the population sells their scrap metals to scrap metal collectors thereby making some income for themselves. There are also, the owners or managers of the scrap metal collection sites who purchase the scrap metals at the cost of 70Frs per kilogram. This is a huge contribution to the economy of Buea in particular since a 20 ton truck of scrap metals will cost millions of francs. The above findings go a long way to justify hypothesis one of the study which states that wastes scrap metal collection is a significant contributor to the socio-economic livelihood of those involved. This is in line with the findings of Cunningham et al., 2003 and Keller (1999) who opine that in order to alleviate poverty, the poor indulge in scrap metal collection and sales to increase their incomes.

Still in line with the second objective of the study, the findings revealed that scrap metal collection leads to environmental sanitation. This is because scrap metals are non-biodegradable and suffocate the soils on the one hand and affects vegetation on the other hand. Field evidence revealed that scrap metals dirty the environment. Thus, areas where scrap metals are dumped haphazard tend not to do well in terms of agriculture or vegetation. The collection of scrap metals therefore falls within the broader framework of the concept of 3Rs in natural resources management (Reduce, Reuse and Recycle). These findings are in line with those of the several authors reviewed who posit that scrap metal collection and management not only serves the socio-economic function but also has environmental benefits.

\subsection{Health Implications of Poor Disposal of Scrap Metals in Buea}

According to findings, $76 \%$ of the sampled population said there are diseases that could be transmitted by poorly disposed wastes (scrap metals) in Buea sub division, and according to $24 \%$ of respondents no diseases can be caused by poor disposal of scrap metals in Buea sub division. From the above awareness, there are diseases which are caused by poorly disposed scrap metals in Buea sub division. Therefore, $64 \%$ of the sampled population believed that the poor management and disposal of scrap metals can be responsible for tetanus in humans. This happens when the employees unknowingly or accidentally step on the sharp ends of scraps. This can lead to a scar caused by the rusted metal, which can lead to these diseases if not well treated and the tetanus vaccine administered immediately. Also, $36 \%$ are of the opinion that it results to malaria mostly through the collection of water by some of these metals which thus acts as a breeding ground for the female anopheles mosquitoes which is responsible for the transmission of malaria parasite into humans. This is in line with the findings of Addul (2010) who highlighted the health implications of poor disposal and collection of scrap metals. This section has presented information to answer the objective of the study 


\section{Dr. Robert Njilla Mengnjo Ngalim \& Jaff Nancy Kila}

which was out to examine the problems involved in scrap metal collection as a strategy for sustainable natural resources management in Buea sub division, Cameroon. It is therefore clear that scrap metal collection, like any other sector, has its own disadvantages both to the environment and to those involved in the business.

\subsection{Responsibility for Disposal of Scrap Metals in Buea}

Respondents were questioned on their awareness of responsibility of scrap metal management by government or individuals. It is evident that $76 \%$ of the respondents believed that scrap metal collection and management of scrap metals should be the responsibilities of both the government and the inhabitants of Buea sub division and $24 \%$ believed it is not the responsibility of both the government and the inhabitants of Buea sub division. This system of scrap metal collection in Buea is not organised. We should use the three-way partnership in scrap metal collection, that is, the private enterprise, government and the council to be able to manage scrap metal collection. The government or the council of Buea should provide a piece of land out of the residential area to build a warehouse for the collection and storage of scrap metals. This will reduce the scrap metals in town because it leads to filth and also provides a breeding ground for mosquitoes which transmit malaria to the inhabitants around the area. Moreover, the government should also help to provide a recycling centre in Buea so as to reduce the scrap metals found in the area and also help the private enterprises who are involved in scrap collection because transportation of scrap to the recycling centre is very expensive for them to be transporting it regularly to the recycling centre of Douala or abroad. Also, the collection of scrap metal by trucks causes traffic congestion especially in the Molyko road since it is one of the highest scrap collection centre in Buea. This road is too narrow and not big enough, so the truck occupies about half of the road thereby causing traffic congestion which can lead to accidents along the Malingo road, especially in the evenings. Furthermore, the scrap metal collection process makes a lot of noise through the offloading, weighing and loading processes, thereby disturbing the inhabitants of the area. The noise also comes from the fact that the sector is not mechanised especially in the cutting and arranging of the scrap metal to smaller pieces. They use axes in cutting and/or reducing the scrap so that it will be easy for transportation from Buea to the recycling centres. In order to mitigate the above negative effects of scrap metal collection, it was realised that, scrap metal collection in Buea is mainly conducted by individuals. This therefore rejects hypothesis two which states that wastes (scrap metal) management is the sole responsibility of the government in Buea sub division. The government has the services of HYSACAM, but this company only collects household rubbish, but is not involved in scrap metal collection for possible recycling.

In relation to objective three which was to examine the problems involved in scrap metal collection as a strategy for sustainable natural resources management in Buea sub division the findings revealed that there are problems encountered both by those collecting the scrap metals and the government. The first major problem is that the activity is not well coordinated since it is a strategy by individuals to alleviate / reduce their poverty situation. As such, the sites for purchase and collection of scrap metals are owned by individuals rather than the government. Also, the collectors of scrap metals have to move from one open dump site to the next to find the scrap metal. They then have to transport the scrap metals mostly in trucks wheel barrows or using their heads to the collection sites for sell. The uncoordinated nature of the activity means that the scrap metal yards are the sole property of the individual concerned. It is true that the council through its daily waste collection activities by HYSACAM also collects scrap metals, but these are not sorted for further recycling. This therefore justifies hypothesis two of the study which states that wastes scrap metal management is not the sole responsibility of the government in Buea sub division. In this light, there is the need for coordination and incorporation of government services in order to ensure cleanliness and orderliness in the scrap metal sector. The above findings are in line with those of the authors reviewed who have demonstrated that scrap metal collection and management in most developing countries is the sole prerogative of the individuals rather than the government.

\section{Conclusion}

This study has investigated wastes generation and management, using the case of scrap metal collection in Buea Sub-division in terms of the spatial distribution and collection, the socio-economic and environmental benefits and the problems involved in scrap metal collection as a strategy for sustainable natural resources management in Buea Sub-division. It can therefore be concluded that scrap metal collection in Buea is predominantly carried out by males between the ages of 21 to 40 
years due to the physical strength needed to carry out the activity. Also, that the neighbourhoods of Great Soppo, Molyko, Bomaka and Bolifamba (Mile 16) have the highest population dealing with scrap metal collection. More so, the study revealed that the types of scrap metals collected in Buea sub division included motor parts, iron rods and gas plates which are generated from abandoned vehicles, uncompleted / demolished buildings and households. It can also be concluded that scrap metal collection in Buea Sub-division fulfils socio-economic and environmental benefits to the population. In terms of socio-economic, the activity has led to employment and generation of revenue for those involved. In terms of the environment, it has led to reduced pollution and enhanced sanitation in the municipality. However, there were problems faced in the collection of scrap metals which included the filth of the places where scrap metals are dumped and the possibilities of generating diseases as a result of standing water. With the growing population of Cameroon and the call by the government towards industrialisation, there will be continuous demand and use of metals for various industrial activities. This means that scrap metals will continue to be generated, leading to continuous exploitation of these metals from nature. In case where there are limited reserves, the answers will be found in scrap metal recycling. Therefore, scrap metal collection and management should be seen as a blessing rather than an activity reserved for jobless people who only fight to feed themselves.

\section{RECOMMENDATIONS}

Based on the findings of the study, it was discovered that the system of scrap metal collection is not organised and well coordinated. We should use the three way partnership in scrap metal collection, that is, by involving the individuals, local council authorities and the government. The council of Buea should provide a piece of land outside the residential areas to build a warehouse where scrap metals can be kept, so as to reduce its impacts on humans and the environment. The government should also help to mechanise the sector through buying of machines which will help in reducing the scrap metal into portable sizes so as to ease transportation. The municipal council should also create a committee of supervision. This body should make available all rules and regulations concerning supervision of scrap metal collection. Any defaulters of these rules and regulations should be punished without exception. This will help reduce the uncoordinated nature of scrap metal collection in Buea.

\section{REFERENCES}

[1] Addul, S. (2010). Environmental and Health Impact of Solid Wastes Disposal at Mangwaneni du Mpsite in Manzini: Swaziland. Journal of Sustainable Development in Africa. Vol. 12, No. 7, 2010.

[2] Adebaw, D.M. (2008). Determinations of Solid Wastes practices in Urban Areas. Department of Geography, University of Lagos, Nigeria.

[3] Asong, F. Z. (2010). Recycling and Material Recovery in Cameroon: Implications for Poverty Alleviation and Ecological Sustainability.

[4] Cunningham P. William, Cunningham A. Mary, Saigo W. Barbara (2003). Environmental Science, A Global Concern, seventh edition. Boston: McGraw Hill Inc.

[5] Fellman D. Jerome, Getis Arthus, Getis Judith and Malinowski C. Jon (2005). Human Geography: Landscapes of Human Activities, 8th Edition, McGraw Hill Higher Education, New York.

[6] Hanan, W., Christopher, M and Verbuecheerz, M. (2002). EU Waste Policies and Challenges for Local, Regional Authorities". EU. Brussels.

[7] Kaseva, M.E. and Gupta, S.K. (1996). Recycling - AN Environmentally Friendly and Income Generating Activity towards Sustainable Solid Wastes Management. Case Study of Dar es Salaam city. Resource Conservation and Recycling, 17, 299-309.

[8] Keller, A.E. (1999). Introduction to Environmental Geology. Upper Saddle River, New Jersey: Prentice Hall.

[9] Kila, J.N. (2014). Wastes Generation and Management: The Case of Scrap Metal Collection in Buea Sub Division, South West Region of Cameroon. Unpublished B.Sc. Research Project. Department of Geography, University of Buea, Cameroon. 
[10] Lambi, C.M. (1999) cited in Lambi, C.M. and Ndenecho, E.N. (2008). Ecology and Natural Development in the Western Highlands of Cameroon: Issues in Natural Resource Management. Langaa Research and Publishing Common Initiative Group, Bamenda, Cameroon.

[11] Medina, M. (2000). Globalisation, Development and Municipal Solid Wastes Management in Third World countries. Tijuana, Mexico. Ecoegio de la Frontera Norte.

[12] Microsoft @ Encarta ( 2009 . (C) 1993-2008 Microsoft Corporation. All rights reserved.

[13] Ntangsi, M.M. and Lum. S.A. (2004): The Impact of the Creation of the University of Buea on the Socio-Economic Life of Molyko. Journal of Applied Social Science. Vol. 4, No 2, 2004, pp. 148-161. University of Buea, Cameroon.

[14] Pariatamby, A. and Tanaka, M. (2014) (Eds) Municipal Solid Waste Management in Asia and the Pacific Islands: Challenges and Strategic Solutions. Springer-Verlag, Singapore.

[15] Shafiul, A.A. and Mansoor, A. (2003). Partnerships for solid waste management in developing countries: Linking theories to realities. Institute of Development Engineering, Water and Development Centre (WEDC), Loughborough University, U.K.

[16] Tsiboe, I.A. and Marbell, E.(2004). "A Look at Urban Waste Disposal Problems in Accra". Masters Thesis ,Roskilde University, Denmark.

[17] United Nations (2008). Human Development Index Report. United Nations, New York.

[18] United Nations Environmental Programme (UNEP) (2009). "Developing Integrated Solid Waste Management Plan Training Manual, Volume 2: Assessment of Current Waste Management Systems and Gaps Therein". Osaka/Shiga, Japan.

[19] United States Environmental Protection Agency (USEPA) (1999). "State and Local Solutions to Solid Waste Management Problems". (http://www.epa.gov). Accessed on 03rd February, 2014.

[20] USEPA (2006). Non-Hazardous Wastes Management Hierarchy. United Nations, New York.

\section{AUTHOR'S BIOGRAPHY}

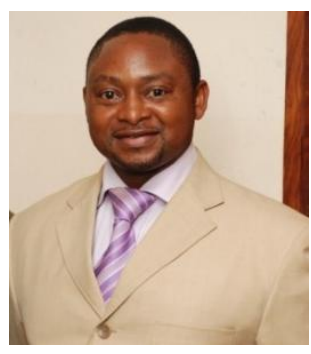

Dr. Robert Njilla Mengnjo Ngalim holds a Bachelor of Science (B.Sc.) Degree, Master of Science (M.Sc.) Degree in Geography with specialisation in Environment and Natural Resource Management and a Doctor of Philosophy (Ph.D.) Degree in Geography with specialisation in Natural Resources Management from the University of Buea, Republic of Cameroon. Dr. Njilla is a Lecturer / Consultant on Specified Assignment, Department of Development Studies, Regional Planning and Project Management programme at the Pan African Institute for Development West Africa (PAID-WA), Buea. He is also the Coordinator for Research in the same Institution. Dr. Njilla has published several articles in peerreviewed learned academic journals in Cameroon and abroad. His research interest include aspects such as Applied Physical Geography, Hydrology and Water Resources Management, Geography of Resources and Environmental management, Contemporary Issues in the $21^{\text {st }}$ Century with particular interest in Climate Change related impacts, and Modern Techniques in Geographic Research and Data Analysis, amongst others. Dr. Njilla is also a Freelance Researcher and Consultant on Environmental and Developmental Issues affecting humankind today. 